\title{
LINGUISTIC VACUUM PREVALENT IN MARGIN/CENTRE POLEMIC
}

\author{
Sadia Riaz ${ }^{*}$ \\ Farhan Ebadat Yar Khan ${ }^{* *}$
}

\begin{abstract}
The research paper addresses the unresolved linguistic vacuum that accounts for the authorial and fictional abrogation and appropriation of language in Lessing's works. This research paper attempts to take a holistic view of these implications. Lessing has used a number of methods to overcome this inadequacy and the abrogation and appropriation of language thus seen is clearly evident in her novel The Grass is Singing. The concepts of hegemony of language by the colonizers and their control over the means of communications as well as the attempts to liberate the language by the blacks were seen in the novel. In order to analyze the post-colonial aspects of the novel, one has to keep in mind the colonial features that were seen in The Grass is Singing. Thus, the process of abrogation and appropriation will be seen through the fictional characters of Mary and Moses. With these characters Lessing highlights the larger reality of the center-margin, colonizer-colonized relation in the novel. Natives on acquiring control over the Language and the ability to control the means of communication then reveal the hollowness of the colonial ideas based on oppression and exploitation of the indigenous people.
\end{abstract}

Keywords: Abrogation, appropriation, marginalization, narration, linguistic vacuum, hegemony

\section{Introduction}

The history of colonialism is a history of conquest, domination and of control. Although one sees colonialism in one form or other throughout human history - be it the raids of Genghis Khan or the rule of the Mughal Emperors. More recently, however, colonialism came to mean the expansion of European countries in to the other continents. It began with a simple desire to explore the new lands discovered. However, as the interest of the white European shifted from exploration to utility of the lands discovered, a marked "devaluation" of natives of these lands also emerged, which, by painting the natives as uncivilized barbarians that needed to be saved, became a source of justification for colonization. ${ }^{1}$

\footnotetext{
* Sadia Riaz, University of Management and Technology, Johar, Lahore

${ }^{* *}$ Farhan Ebadat Yar Khan, Ph.D. Professor of English, Higher Education Department Government of Punjab ${ }^{1}$ Chinua Achebe, "My Home Under Imperial Fire," in Home and Exile. (New York: Oxford University Press, 2000), 29
} 
An important tool of dominion and control seen during colonization was hegemony over language. In the British colonies of Africa and elsewhere, English was established as a language that was vastly superior to the language of the natives - as was the case with everything British in the colonies. This supposedly superior language was imposed on the natives who were comfortable with its usage (or taught its proper usage for that matter). Control over language was both at the written and the spoken level - which ultimately leads to establishing hegemony over the means of communication. This control of the means of communication just like the European literature about Africans helped in firmly entrenching fixed notions about the Africans, since, the voice of the natives was not heard or was severely curtailed. This also widened the gap between the natives and their masters - a linguistic gap which was a consequence of the control over language by the colonizers.

With the end of the colonization, the natives or the colonized attempted to free themselves from the colonial domination and one aspect of this fight for freedom was language. The post-colonial aspects of abrogation and appropriation of language came into play here as to have their voice heard. These efforts led to the plethora of writing that eventually became a part of the literary field of post-colonial Literature

\section{Literature Review}

Post colonialism is a phenomenon and a post-modern intellectual discourse that emerged in the 1978 in the analysis of various discourses. In order to understand what is postcolonialism and Postcolonial theory it is extremely important to know the background of post-colonialism. Post-colonialism emerged from the process of colonization and in turn embodies imperialism.

Edward Said in his "Culture and Imperialism" very explicitly gives the working of the societies and also sums up the relationship between societies. He writes:

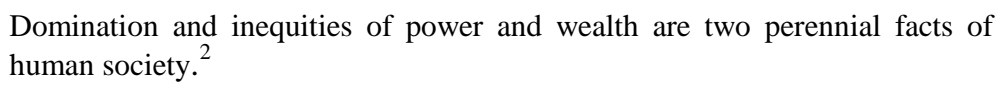

Colonization was one such event that changed the face of earth with the expansion of different European countries beyond its territories. The event of colonization not only shaped history of the world but also affected literature. After colonization the subsequent process of decolonization began with the advent of World War II, defined and constructed the realities and relationships between the colonizer and the colonized as such, Ania Loomba writes:

Colonialism everywhere locked the original inhabitants and the new comers into most complex and traumatic relationships in human history. ${ }^{3}$

Colonialism was the means and ends of imperialism because these two almost similar phenomena exploited the indigenous people along with affecting their psychologies,

\footnotetext{
${ }^{2}$ Edward Said, Culture and Imperialism (New York:Vintage Books, 1993), 20.

${ }^{3}$ Ania Lomba, Colonialism/ Post Colonialism (New York: Routledge, 2000), 20
} 
giving them a sense of alienation. Edward Said makes the distinction between imperialism and colonialism, by writing:

Imperialism means the practice, the theory, and the attitudes of a dominating metropolitan Centre ruling a distant territory; colonialism, which is almost always a consequence of imperialism in implanting of settlements on distant territories. $^{4}$

This practice very clearly sets up imperialism as a theory and colonialism as a practice. The notion is very important in understanding postcoloniality as it makes the term complex. The notion of Post colonialism which is taken to be the aftermath of colonialism loses its significance. Bill Ashcroft and Helen Tiffin write about imperialism:

Colonialism developed an ideology rooted in obfuscatory justification, and its violent and eventually unjust processes became increasingly difficult to perceive behind a liberal smoke screen of civilizing 'task', paternalistic' development and 'aid'.

Postcolonial theory refers to the phenomenon of colonization and decolonization therefore the prefix post becomes very important. Just as the prefix post in post modernism baffles many critics similarly the prefix in post colonialism bewilders the comprehension of the term itself. The prefix in post modernism literally alludes to something after the contemporary and creates problems for definition of the term. Notion of something after the contemporary becomes absurd leaving it indefinable. In the same way post in Post colonialism and postcolonial theory makes the term debatable.

Post implies aftermath of something but to take post colonialism as aftermath of colonialism creates problems and according to Ania Loomba complicates the matter in two ways; temporal and ideological. She explains the temporal meaning by saying that post-colonial cannot be used in single sense, because decolonization of different countries did not take place simultaneously. For instance, decolonization of America took place in the eighteenth century. In Asia and Africa decolonization took place in 1940s, and later. Hence, the boundaries of beginning of post-colonialism become blurred. Ania loomba then refers to the ideological confusions aroused by postcoloniality. She quotes critic's view,

If the inequities of colonial rule have not been erased, it is perhaps immature proclaim the demise of colonialism. A country may be both post-colonial and neo-colonial at the same time. ${ }^{6}$

These interpretations make the term ambivalent and inadequate for defining what exactly post colonialism is. In this regard again Ania Loomba writes,

\footnotetext{
${ }^{4}$ Edward Said, Culture and Imperialism, 8.

${ }^{5}$ Bill Ashcroft, Gareth Griffiths and Tiffin, Helen, Post-Colonial Studies (London and New York: Rutledge, 2007), 108.

${ }^{6}$ Ania Lomba, Colonialism/ Post Colonialism, 12
} 
It has been suggested that it is more helpful to think of post-colonialism not just as coming literally after colonialism and signifying its demise, but more flexibly as the contestation of colonial domination and the legacies of colonialism. $^{7}$

Postcoloniality came into literature when the controlling powers of representation were critically studied. This was set forth in 1978 by Edward Said's book "Orientalism" which was the beginning of the post-colonial theory. This book analyzed the notion of Orient set forth by the West. Edward Said's analysis of the fact that much of the Western notions about the colonized people was based on their prejudice against the Muslim and the colonized states. He divided these colonizing states and colonizer's into binary opposites of Orient and Occident and established the fact that both are mutually depended on each other because it is the East that gives identity to the West. Another critic Gayatri Spivak wrote an essay 'Can the subaltern speak?' in 1985. Through the concept of 'subaltern', she brought forth the notion of oppressed classes being given a voice and also brought into literature the problem of representation of these people. Since this essay raised another question, if it is be possible for the writers to touch the consciousness of subjugated people or not. This essay was of the utmost importance for the development of the postcolonial theory.

Postcolonial theory in a way disturbs the order of the world by threatening the shift of power dynamics, demanding equality, objective and impartial perspective. For instance, in The Grass is Singing, one sees the reversal of power politics between a black man, Moses and a white woman, Mary which will be discussed in the next section.

\section{Methodology}

The present research paper employs qualitative research methodology based on the critical analysis of the novel The Grass is singing by Doris Lessing within the theoretical framework of Post colonialism. In the selected text, it shall be traced out that how Lessing's novel, The Grass is Singing rejects stereo-typical notions of the colonized and the colonizer. The novel will be analyzed within dynamics of culture and power through metaphorical, abrogative, appropriative, and deconstructive ways of linguistic manipulation. The concept of abrogation of language is thereby regarded as a denial of the privilege of English language over the means of communication. "It is a refusal of the categories of the imperial culture, its illusory standard of correct usage, and its assumption of a traditional and fixed meaning in words" ${ }^{8}$ On the other hand, the appropriation of language can be taken as the process of restructuring the language to 'bear' the burden of the colonial cultural experience. In The Grass is Singing, the texture of this abrogation and appropriation of language is implied on various levels, both concrete and abstract. This research paper attempts to take a holistic view of these implications. In order to do so, it is important to signify the ideology of language itself and how it intertwines with various cross-cultural connotations.

\footnotetext{
${ }^{7}$ Ania Lomba, Colonialism/ Post Colonialism, 16

${ }^{8}$ Bill Ashcroft, Gareth Griffiths and Tiffin, Helen, Post-Colonial Studies, 40
} 


\section{Discussion}

The linguistic aspect of post-colonialism was not merely related to the voice of the suppressed. The colonizing power was also a part of it in the sense of its settlers who went to the colonized lands and found their language inadequate in describing the strange landscape and the new feelings as well as the sense of alienation and of displacement felt by them. Therefore, the need to change English language so as to give an apt description of the new environment was felt. Eventually, the literature of the white settlers also became a part of post-colonial writings the themes of inadequacy of language, a feeling of alienation and search for identity were seen in the writings of both the colonizers and the colonized.

Doris Lessing is one such writer. A white settler in a pre-dominantly black country, Lessing was also faced with the dilemma of the inadequacy of language. However, she used number of methods to overcome this inadequacy. The abrogation and appropriation of language is clearly evident in her novel The Grass is singing. The concepts of hegemony of language by the colonizers and their control over the means of communications as well as the attempts to liberate the language by the blacks are seen in the novel. In order to analyze the post-colonial aspects of the novel, one has to keep in mind the colonial features that were seen in The Grass is Singing. One such colonial feature and an important aspect of the domination and control of the Black was seen through control of the whites over the means of communication i.e. language use. Please The control over Language is "key feature of colonial oppression... rather than the control over life and property or even language itself... the control is always manifested by the imposed authority of a system of writing, whether writing already exists in the colonized culture or not." 9 A good example of this hegemony over language form The Grass is Singing with the following newspaper report about Mary's murder and Moses motives.

Mary Turner, wife of Richard Turner, a farmer at Ngesi, was found murdered on the front verandah of their homestead yesterday morning. The houseboy, who has been arrested, has confessed to the crime. No motive has been discovered. It is thought he was in search of valuables. ${ }^{10}$

This report - as the unfolding plot of the novel highlighted - had given a false picture of the events leading up to the murder of Mary by Moses. This included the fact that Mary and Moses had in fact been in an illicit physical relationship and Mary's desire to break free from Moses ultimately led to her murder. This report also gave a stereotypical image of Moses and reinforced the beliefs of the whites about the blacks. This was seen in the following lines with Lessing's description about how the report had been received by the ordinary white readers:

\footnotetext{
${ }^{9}$ Bill Ashcroft, Gareth Griffiths and Tiffin, Helen, Post-Colonial Studies, 99

${ }^{10}$ Doris Lessing. The grass is singing (London: Heinemann Educational.1994), 9
} 
People felt a little spurt of anger mingled with what was almost satisfaction ...When natives steal, murder or rape, that is the feeling white people have. ${ }^{11}$

Those who knew nothing about the players involved in the murder drama did not attempt to question the report which was ambiguous at best. The image of the native population as beasts, therefore, was constantly reinforced through the means of communication which was in the case of Moses a piece of journalism. The fact that Moses couldn't be seen as the hardworking worker and a complex individual in his own right showed how the whites with their control over the means of communication were able to distort facts and realign them to their version of reality. The other side of the story and a different perspective was never seen because people with that perspective had no control over Language and therefore, no voice of their own.

The perspectives of the whites were presented through their own language, which in the case of Southern Rhodesia was English. It was through the English language that the domination over the Blacks strengthened. Blacks could and did communicate amongst themselves in their local dialects. However, any attempt to do so in the presence of whites was not appreciated because as exhibited by Mary, the whites would than show signs of unease and insecurity. When Moses spoke in his native tongue to Mary she repressively told him "Don't talk that gibberish to me." (Lessing, 1994) However, since it was the language of the colonial masters, any attempts to speak English by the natives were also not well-received and was seen as their "cheek" by their masters. This was especially the case if the language of the colonial masters was used to put across their point of view or desires. The interaction between Moses and Mary in the novel revealed Mary's attitude as such,

$$
\text { "I ... want ... water.” (119) }
$$

Mary was outraged and retaliated. She hit Moses with her whip. The only form of English communication that was acceptable from the Blacks was, if the manner of their English speech highlighted their lower station in life. In the interactions between Mary and her first native servant Samson, one saw that Samson only understood and spoke certain English phrases that indicated a servile attitude such as Samson says to Dick, "very nice, very nice, boss," (57) and later to Mary "bass has keys (to the storeroom)" (59) while showing Mary her new home. English, therefore, was a language of command but Mary was ultimately forced to learn Kitchen Kaffir because "she was unable to make Samson understand her." (60) Language of the colonial masters therefore became the "medium through which a hierarchical structure of power is perpetuated." $" 12$ The whites had power because they dominated language and through it the means of communication and therefore the realities of the world around them could be changed and molded to their purpose as was seen through the newspaper report about the murder.

These natives had no choice but to attempt to learn Kitchen Kaffir an amalgamation of their local languages such as Ndebele and Shona with English. This became the

${ }^{11}$ Ibid., 9

${ }^{12}$ Bill Ashcroft, Gareth Griffiths and Tiffin, Helen, Post-Colonial Studies, 7 
language of communication between the two communities or rather the servants and the masters. Mary Turner in The Grass is singing learned to do the same. The use of kitchen kaffir by the whites, however, was also a form of dominion - a language through which they could convey their orders to the blacks in a language they could understand for the most part. Kitchen kaffir did not give a new voice to the natives. This lack of an effective means of communication led to the silencing of the native voice in colonial Southern Rhodesia.

This silencing was along the lines of the Black inability to break free from the tyranny of their masters' and they therefore, adopted a non-threatening and passive attitude around their white masters. An example of this was seen through Lessing's description of one of Mary's houseboys who "had years of experience working for a white women who treated him as if he were a machine; and he had learned to present a blank, neutral surface, and to answer in a soft neutral voice."(68) Lessing's depiction of Moses was the same: "...he behaved as if he were an abstraction, not really there, a machine without a soul."(152) However, even this blank façade of the natives was misunderstood by Mary who would become angry when he (one of her houseboys before Moses) would never meet her eyes. She did not it was part of the native code of politeness not to look superior in the face; she thought it was merely further evidence of their shifty and dishonest nature."(68) Evidently, lack of communication between blacks and whites at all levels be it spoken or verbal resulting in the silence. Whites had a deeply rooted belief in Africa as the inferior continent populated by colored bigots who were barbaric and illiterate.

Feeling awkward, silence on the part of the whites was also reflective of many emotional pangs they were going through. A telling evidence of this silence was seen after Mary's murder when Charlie Slater and the Sergeant Denham acted in compliance with each other without having to openly talk about it. The episode of murder was dealt with in a communicative silence in which it was through their body language and expressions that some evidence of what they were feeling was seen, "the profound instinctive horror and fear." (20)

The silence of the blacks was that of a race that was "always in the margins ... never qualified as the norm ... not authorized to speak." "13 The silence between the blacks and whites, the servants and masters, the margin and the center was the "profound silence between cultures which finally cannot be traversed by understanding." ${ }^{14}$ The silence of the whites meanwhile was a consequence of the values of the center and of their ideologues that was "still the source of legitimization," 15 And yet there was violence beneath the surface that one could not find words to describe and where language failed humans resulting in a linguistic vacuum. The linguistic vacuum which was a result of a lack of communication, a lack of control over means of communication and even a lack of control over language itself that led to the gradual realization of the need to break free from this silence and vacuum between the center and the margin. Here several levels of

${ }^{13}$ Robert J.C. Young, Post-Colonialism: A Very Short Introduction (Oxford and New York: Oxford University Press), 13

${ }^{14}$ Bill Ashcroft, Gareth Griffiths and Tiffin, Helen, Post-Colonial Studies, 9

${ }^{15} \mathrm{Ibid}, 21$ 
marginality can be seen. Blacks as the inferior being and the colonized were on the margins. White women being a part of a patriarchal society and living their lives as social beings led a marginalized existence of their own, which was exhibited by the derisive attitude of her friends towards the manner in which Mary led her life (give examples). The settlers from Europe living in the colonies also became a margin when they could no longer relate to the center. A cultural reference of this was seen during Dick Turner's tirade against the "nigger-lovers from England" (138) those influence on the local Government meant that they would no longer "send out Lorries and soldiers and bring them to the farmers by force." (138). the realization of these facts led to a discourse of abrogation and appropriation of language and to shake off the shackles of their marginalities. For the Blacks, it meant taking control of the means of communication and their domination and for whites; it meant a process of trying to create their own identity and sense of belonging in the colony.

The abrogation and appropriation of language was seen at two levels within the novel The Grass is singing. One was the efforts of the author herself and other was at the level of the plot and the storyline.

In The Grass is Singing Lessing dealt with the alienation of the settlers who were faced with the prospect of describing an alien environment with the language that was illequipped to do so. This sense of displacement existed as long as the language of the colonial center was taken as the norm. Thus in order to acclimatize them to the new environment, the hegemony of the language of the center had to be broken, which was known as the process of abrogation or the "denial of the privilege of English." 16 This was followed by the process of appropriation, which was "capturing and remolding the language to new usage". ${ }^{17}$ The method of appropriation used in The Grass is singing was the incorporation of words from a different language in to the text that were not translated. This was seen throughout the novel through Lessing's use of words like "kopje," "sjambok," "mealies," "velds," "dorp" etc. All of these words were from the Afrikaans language which was a variant of Dutch. However, never once did Lessing give the meaning of the words which had to be inferred from their usage or left untranslated. However, through the usage of these words Lessing was able to highlight the distinctiveness of her setting and give an apt description of her environment. The built up of this environment would not have been possible if Lessing had used the English word "small hill" instead of "kopje." Hill had an association of meanings with it which was a consequence of its usage in relation to the English countryside with its green hills and damp environment. The word kopje in conjunction with the usage of other natural imagery such as "red soil" and "bushes" allowed Lessing to draw an image of dry little hills with a barren, open land surrounding it.

Lessing also made use of a method of appropriation called glossing but it was not an explanation of untranslatable words or unfamiliar slang. Rather it was an ironic commentary of the events as well as giving a different perspective of the images and the situations that were being painted, which was given within brackets. One such use of the

${ }^{16} \mathrm{Ibid} ., 11$

${ }^{17}$ Ibid., 13 
bracket was in the second chapter: "She knew (the phrase was in the air) that the natives were getting "cheeky." (35-36). Mary had no personal contact with natives at this point of the novel. Through the use of the brackets, Lessing gave a break to the narrative and forced one to look at what the words within the brackets meant. In this case it hinted at not only Mary's lack of personal experience with the natives but also the assumptions about these natives were taken as facts. Mary knew that the natives were getting "cheeky" and yet she had no solid basis for this knowledge or assumption. It was therefore, not merely a humorously ironic comment on Mary's lack of awareness of the realities around her but it also hinted at the colonial ideology which was based on the assumption of black inferiority and the superiority of the British race. Thus, Lessing used the language of the colonizers against the colonizers by exposing the hollowness of their ideals. The abrogation and appropriation of language also took place at the fictional level in the novel. This was exhibited especially through the interactions of Moses and Mary.

Moses was seen as a fairly well-educated man within the laborer community. His interactions with Mary revealed a fair articulation of the English language compared to other slaves. It was revealed that as a boy he had been taught to read and write by the missionaries. However, knowledge of the language of the colonizers or his ability to communicate fairly well in their language was not enough to be seen as an individual and a human being rather than a machine. As explained in The Empire Writes Back:

...the nexus between language and power lies in the ability to control the means of communication. ${ }^{18}$

There are lines in another novel by Lessing, Martha Quest depicting Martha's absorption and observance of the landscape around her. 'In the literature that was her tradition, the word 'farm' evokes an image of something orderly, compact, cultivated; a neat farm house in a pattern of fields. Martha looked over a mile or so of bush to a strip of pink ploughed land; and then the bush, dark green and somber, climbed a ridge to another patch of exposed earth, this time clayish yellow; and then ridge after ridge, fold after fold, the bush stretched to a line of blue kopjes. The fields were a timid intrusion on a landscape hardly marked by man;... and then nothing to disturb that ancient downpeering eye, nothing that a thousand generations of his hawk ancestors had not seen.'

Here at first, the canonical tradition of English literature and language is being implicitly criticized for its insufficiency to account for the word 'farm' in foreign cultures. The permittivity of the landscape notwithstanding, Martha's literature is not enough to appropriate her present reality which is mundane, monotonous and reeks of stagnation. For this reason, the vastness of the landscape itself causes her 'only the pricking feeling of claustrophobia'.

Lessing thus clearly abrogates the concept of a universal linguistic code and appropriates English language by incorporating native words like "kopje", "banjo" in her depiction of landscape and culture. Her primary tool in her novel, Martha Quest,

${ }^{18}$ Bill Ashcroft, Gareth Griffiths, and Helen Tiffin, "Introduction" in The Empire Writes Back: Theory and Practice in Post-colonial Literatures (London and New York: Routledge, 1989), 9. 
however, is use of imagery, colours, and metaphor. At a later stage in the novel, she uses binary oppositions of light and dark and perpetuates them to a neutralizing effect. The dichotomy is appropriated at equal level in the depiction of beauty and terror till the ellipses exhaust the comparison. "Colour and light: the town was bombarded by light... The greens of the foliage were deep and solid and shining, but filmed with dust; like neglected water where debris gathers...How terrible October is! Terrible because so beautiful, and the beauty springs from the loaded heat, the dust, the tension; for everyone watches the sky, and the heavy trees along the avenues... One cannot remember the smell of flowers without the smell of dust and petrol; one cannot remember that triumphant orchestra of colour without the angry, white-hot sky. One cannot remember..." (29)

In terms of the native impact, linguistic appropriation is also exposed in the depiction of a minor character Mr. Parry. "Mr. Parry's Welsh speech had lost nothing of its lilt and charm; but the phrases had worn slack; his 'Look you' sounded more like 'Look ye'; and when he used the Welsh 'whatever', it came haphazard in his speech, with a surprised, uncertain note."(47) Example of this is on the next page where Mr. Parry shouts to his native servant, 'Come ye, now, you lazy black loafer, and do it quick whatever you do, and listen well, now.' This is the most pertinent reference to authorial and fictional appropriation of speech through code-switching, to the effect that the writer achieves the 'dual result of abrogating the Standard English and appropriating English as a culturally significant discourse. ${ }^{19}$

Further in The Grass is singing, through the control of means of communication, the whites were able to draw a picture of Moses as a mere thief. The control was not in Moses hands but he still showed signs of coming out of shell to guard his self-esteem. An example of this was the fact that Moses deliberately flouted Mary's rules and even communicated to her his need for water. In doing so he forced Mary to notice him as an individual. When Mary inadvertently walked in on him while he was bathing Moses, "stopped and stood upright...his body expressing resentment."(143). Moses, therefore did not passively accepted this invasion of his privacy and instead forced Mary to retreat. At one point, Moses decided to leave his job. Mary, who for years had been battling demons was not equipped to battle, broke down and entreated with him not to go away. This was the moment when the balance shifted. Moses a symbol of the black race saw the weakness of Mary, the emblem of a gradually weakening colonial rule. At this point in the storyline, Moses crossed the line of demarcation between whites and blacks. "He was loath to touch her, the sacrosanct white woman," (151) and yet he did so in order to help Mary regroup. Meanwhile, Mary was engulfed with a "terrible dark fear" (152). This fear was a consequence of breaking one of the sacred commandments of the colonial rule: "Thou shalt not let your fellow whites sink lower than a certain point; because if you do, the nigger will see he is as good as you are" (178). It was too late Since, Mary had already seen it.

\footnotetext{
${ }^{19}$ Bill Ashcroft, Gareth Griffiths, and Helen Tiffin, "Replacing Language", The Empire Writes Back: Theory and Practice in post-colonial literatures, (London and New York: Routledge, 1989), 40.
} 
He used his new found knowledge to force Mary into treating him as a human being. Mary attempted to regain the upper hand in her relation with Moses by being harsh with him. However Moses did not allow it. Instead of acting as an automaton, he "looked at her straight in the face and said in a voice that was disconcertingly hot and reproachful: 'Madame asked me to stay. I stay to help Madame. If Madame cross, I go.'... The resentful heat of his voice said that he considered she was unjust." (153) Mary felt "helpless" and at this point Moses also started to encroach upon the hegemony of the British over the language by than speaking to her in English. Mary felt this "impertinence" but she let it go because control was slipping from her hands as Moses slowly but surely started to shed the garb of a subservient being. Lessing described the new relationship between them in the following words:

\begin{abstract}
She felt as if she were in a dark tunnel, nearing something final, something she could not visualize, but which waited for her inexorably, inescapably. And in the attitude of Moses, in the way he moved or spoke with that easy, confident, bullying insolence, she could see that he was waiting too. They were like two antagonists, silently sparring. Only he was powerful and sure of himself, and she was undermined with her fear. (167)
\end{abstract}

These lines show the completion of the abrogation and appropriation process. Moses had rejected the position of English as a superior language as well as the superiority of the colonizers. By first starting the process of dominating Mary in her moment of weakness, he was now able to appropriate the language and use it the way he chose to. He understood Mary's fears and was able to communicate to her his understanding of her emotions as well his attitudes and personality, therefore removing the linguistic gap between the two cultures and overcoming the silence that was a result of miscommunication and the monopoly of the British. Mary could hear his voice now, which became a symbol of the voice of the colonized that could now be heard by the colonizers by usage of their own language. This process was also described in The Empire Writes Back:

"Only by denying the authenticity of the line (separating the colonized-colonizer, margin-center) and taking control of the means of communication can the post-colonial text overcome (the) silence." 20

After abrogating and appropriating the language and taking control of the means of communication, Moses proceeded to gain the power that the re-use of the language of the colonizers allowed him and then use that power over Mary. After the affair between Mary and Moses began, Moses started to work "slackly," and also talked to Mary "with a rough offhand rudeness" and in a tone of "surly indifference, but with a note of selfsatisfaction, of conscious power" (177) After Moses and Mary realized that Dick's new manager Tony Marston knew the reality of the relation between the two of them, Mary attempted to break free of the control Moses had over her, and tried to "assert herself" (188). However, Moses would not relinquish his control and asserted his domination by murdering Mary. This murder became a symbol of the end of the colonialism and the center-margin relationship. Taking control of the means of communication, language

${ }^{20}$ Bill Ashcroft, Gareth Griffiths, and Helen Tiffin, The Empire Writes Back, 21 
and power, ultimately helped him in killing the symbol of colonialism. This showed that by abrogating and appropriating the language, the colonized could overthrow the center. Just as the control over the means of communication allowed them to paint a reality that suited the colonizers, the same process could now help the margins in constructing their own reality free of the hegemony of language of the colonizers.

\section{Conclusion}

The process of abrogation and appropriation was clearly seen the way natives employed it to contest imperial gaze, especially through the fictional character of Moses. Lessing highlights the stark reality of the center-margin, colonizer-colonized relation in the novel The Grass is singing. The colonizers took control by exercising hegemony over the natives through their language which embodies culture. The natives' also acquired agency by creating ruptures in the Language of the master and therefore, disturbed the center/margin polemic in the novel. The hollowness of the colonial ideas was exposed when the tools of the colonizers hit them back with great severity and became the victim of their own creation.

\section{Bibliography}

Ania Lomba, Colonialism/ Post Colonialism (New York: Rout ledge, 2000)

Bill Ashcroft, Gareth Griffiths and Tiffin, Helen, Post-Colonial Studies (London and New York: Rutledge, 2007)

Bill Ashcroft, Gareth Griffiths, and Helen Tiffin, "Introduction" in the Empire Writes Back: Theory and Practice in Post-colonial Literatures (London and New York: Rout ledge, 1989)

"Replacing Language"

The Empire Writes Back,

Chinua Achebe, "My Home Under Imperial Fire," in Home and Exile. (New York: Oxford University Press, 2000)

Doris Lessing. The grass is singing (London: Heinemann Educational.1994)

Edward Said Culture and Imperialism (New York: Vintage Books, 1993).

Robert J.C. Young, Post-Colonialism: A Very Short Introduction (Oxford and New York: Oxford University Press) 